\title{
Correction to: Common bean resistance to Xanthomonas is associated with upregulation of the salicylic acid pathway and downregulation of photosynthesis
}

Justine Foucher ${ }^{1}$, Mylène Ruh ${ }^{1}$, Anne Préveaux ${ }^{1}$, Sébastien Carrère ${ }^{2}$, Sandra Pelletier ${ }^{1}$, Martial Briand ${ }^{1}$, Rémy-Félix Serre ${ }^{3}$, Marie-Agnès Jacques ${ }^{1}$ and Nicolas W. G. Chen ${ }^{1 *}$

Correction to: BMC Genomics 21, 566 (2020) https://doi.org/10.1186/s12864-020-06972-6

Following the publication of the original article [1], it was reported that the correct image for Fig. 1 was missing. The correct Fig. 1 is provided here and has been added to the original article.

Furthermore, Table 2 was missing the indication of which values indicate non differentially-expressed genes (i.e. genes with $-1.5<\log 2 \mathrm{FC}<1.5$ and/or adjusted $p$ value $\geq 0.05$ ).

The original article has been updated.

\section{Author details}

'IRHS, INRAE, AGROCAMPUS OUEST, Université d'Angers, SFR4207 QUASAV, 42, rue Georges Morel, F-49071 Beaucouzé, France. ${ }^{2}$ CNRS, UMR 2594, Laboratoire des Interactions Plantes-Microorganismes (LIPM), F-31326 Castanet-Tolosan, France. ${ }^{3}$ INRAE, US 1426, GeT-PlaGe, Genotoul, Castanet-Tolosan, France.

Published online: 23 September 2020

\section{Reference}

1. Foucher J, Ruh M, Préveaux A, et al. Common bean resistance to Xanthomonas is associated with upregulation of the salicylic acid pathway and downregulation of photosynthesis. BMC Genomics. 2020;21:566 https:// doi.org/10.1186/s12864-020-06972-6.

The original article can be found online at https://doi.org/10.1186/s12864020-06972-6.

* Correspondence: nicolas.chen@agrocampus-ouest.fr

${ }^{1}$ IRHS, INRAE, AGROCAMPUS OUEST, Université d'Angers, SFR4207 QUASAV, 42, rue Georges Morel, F-49071 Beaucouzé, France

Full list of author information is available at the end of the article

C C The Author(s). 2020 Open Access This article is licensed under a Creative Commons Attribution 4.0 International License, which permits use, sharing, adaptation, distribution and reproduction in any medium or format, as long as you give appropriate credit to the original author(s) and the source, provide a link to the Creative Commons licence, and indicate if changes were made. The images or other third party material in this article are included in the article's Creative Commons licence, unless indicated otherwise in a credit line to the material. If material is not included in the article's Creative Commons licence and your intended use is not permitted by statutory regulation or exceeds the permitted use, you will need to obtain permission directly from the copyright holder. To view a copy of this licence, visit http://creativecommons.org/licenses/by/4.0/ The Creative Commons Public Domain Dedication waiver (http://creativecommons.org/publicdomain/zero/1.0/) applies to the data made available in this article, unless otherwise stated in a credit line to the data. 


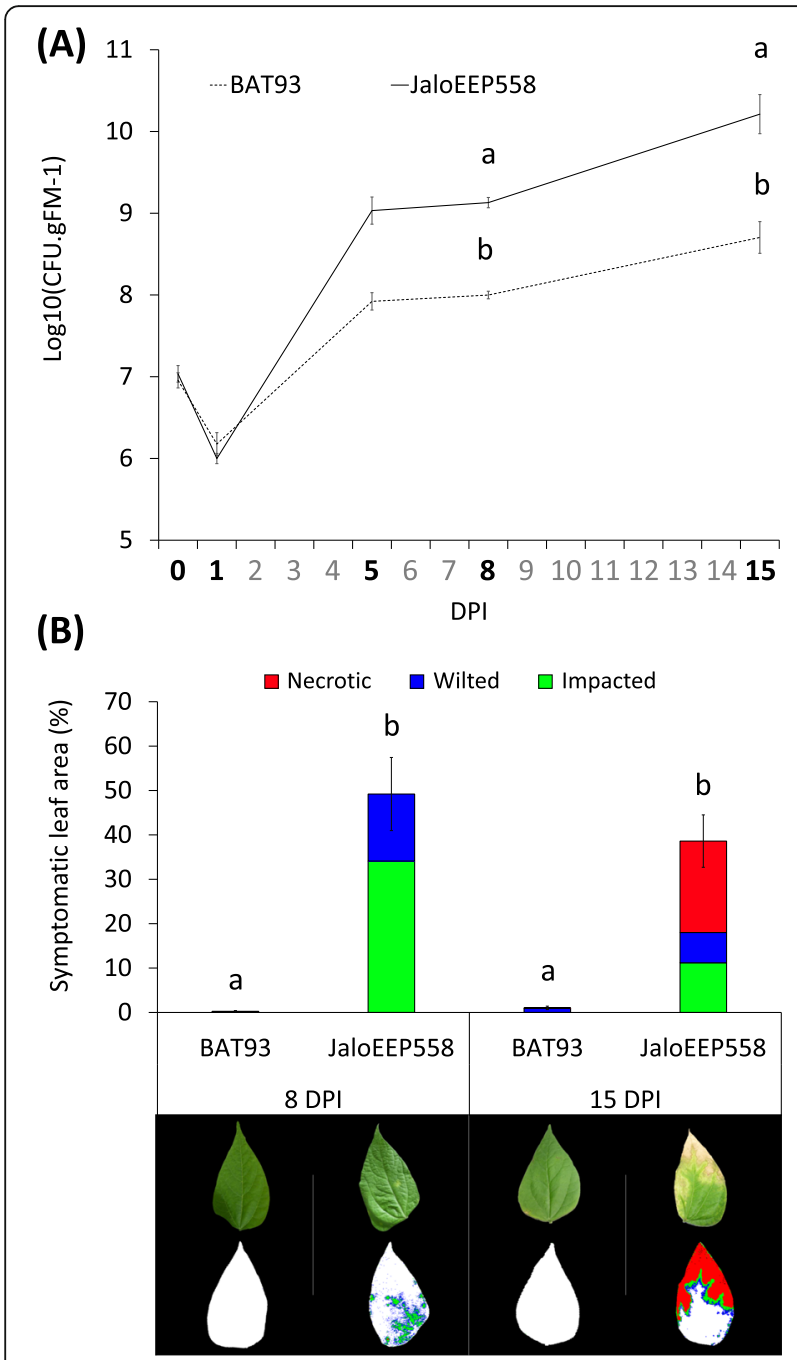

Fig. 1 Pathogenicity of strain CFBP6546R on BAT93 and JaloEEP558. Bacterial population sizes over time on BAT93 (dotted line) and JaloEEP558 (full line) (a). Quantification of symptoms assessed by chlorophyll fluorescence imaging at 8 and 15 DPI (b). Total symptomatic areas corresponded to the sum of impacted, wilted and necrotic tissues defined by using Fv/Fm tresholds as previously compared to visual inspection [52]. Error bars represent the standard errors of the means for three biological replicates. Below the histogram are examples of leaflets presenting symptoms representative of each condition, obtained by chlorophyll fluorescence imaging (top) or visible imaging (bottom). Letters indicate significantly different groups (Mann-Whitney test, $p$-value < 0.05). CFU: colony-forming units. gFM: grams of fresh materials. DPI: days post inoculation 